\title{
The potential of vaccines for the control of AIDS
}

\author{
MARGARET I JOHNSTON PhD, PATRICIA E FAST MD PhD, MARY CLARE WALKER PhD, \\ DANIEL HOTH MD
}

\begin{abstract}
MI Johnston, PE Fast, MC WALKer, D Hoth. Potential of vaccines for the control of AIDS. Can J Infect Dis 1994;5(Suppl A):36A-41A. The goal of a prophylactic human immunodeficiency (HIV) vaccine is to elicit immune response(s) that will, upon subsequent exposure to HIV, prevent infection and/or disease. On the other hand, therapeutic administration of a vaccine to an individual in whom infection is already established might benefit the individual by augmenting existing functional immune responses or inducing new ones. Development of vaccines for the prevention of AiDs offers unique challenges. Concerns regarding the safety of attenuated and whole-killed products have led to the pursuit of alternative designs, including recombinant proteins, vectors and particles, synthetic peptides and naked DNA. Seven recombinant envelope, two recombinant vector and four other candidate vaccines that have entered into phase 1 trials in noninfected individuals have proven safe to date, and have differed in their ability to induce functional antibody and cytotoxic T lymphocytes. Two recombinant envelope products have recently progressed to phase 2 testing. Five envelope-based and six other products have entered trial in HIV-infected individuals and have appeared to be safe. Evidence of new antibody, increased $\mathrm{T}$ cell proliferation and increased cytotoxic T lymphocyte activity have been reported. Additional placebo controlled trials will be required to evaluate the impact of therapeutic vaccination on CD4 cell count. viral burden and clinical end-points. The status of HIV/AIDS vaccine development is reviewed, with emphasis on the challenging task of finding an efficacious, safe, prophylactic vaccine.
\end{abstract}

Key Words: AIDS, Clinical trials, Human immunodeficiency virus, Vaccines

\section{Potentiel des vaccins dans la lutte contre le SIDA}

RÉSUMÉ : Le but d'un vaccin contre le virus de l'immunodéficience humaine (viH) est de déclencher des rẻactions immunitaires qui, lors d'une exposition subsêquente au viH. préviendront l'infection ou la maladie. D'autre part, l'administration thêrapeutique d'un vaccin à une personne déjà infectée pourrait offrir à cette personne lavantage de rehausser sa propre réponse immunitaire ou d'en déclencher de nouvelles. Le développement de vaccins pour la prévention du SIDA offre un potentiel unique. Les craintes qu'inspirent les produits atténués ou tués à l'égard de l'innocuité ont stimulé la recherche en vue de trouver des modèles différents, notamment des protéines, des vecteurs et des particules recombinantes, des peptides synthétiques et de l'ADN dénudé. Parmi les vaccins qui sont entrés dans des essais de phase I chez des sujets non infectés et qui se sont révélés sans danger jusqu’à présent, notons-en sept à base d'enveloppe recombinante, deux à base de vecteur recombinant et quatre d'autres types. Leur capacité à induire la production danticorps et de lymphocytes T cytotoxiques fonctionnels est variable. Deux des produits à base d'enveloppe recombinante ont récemment progressé vers des essais de phase II. Cinq produits à base d'enveloppe et six produits d'autres types font l'objet d'essais auprès de sujets infectés au viH et semblent êgalement être sans danger. On a pu observer la présence de nouveaux anticorps, la prolifération accrue de cellules T et une activité plus grande des lymphocytes T cytotoxiques. D’autres essais contrôlés avec placebo seront nécessaires pour évaluer les répercussions d'une vaccination thérapeutique sur la numération des cellules $\mathrm{CD} 4$, sur la charge virale et les paramètres cliniques. Lévolution des vaccins contre le $\mathrm{VIH} / \mathrm{SIDA}$ est passée en revue et l'on insiste sur le défi que reprẻsente la découverte d'un vaccin prophylactique sûr et efficace.

Division of AIDS, National Institute of Allergy and Infectious Diseases, National Institutes of Health, Bethesda, Maryland. USA Correspondence and reprints: Dr Margaret I Johnston, Division of AIDS. NIAID. National Institutes of Health. 6003 Executive Blvd, Room 2A16. Bethesda, MD 20892. USA. Telephone (301) 496-0545. Fax (301) 402-1505 
$\mathrm{S}$ INCE THE DISCOVERY OF AIDS AND ITS ETIOLOGICAL AGENT, the human immunodeficiency virus (HIV), researchers from all sectors of the scientific community have been challenged to find effective therapies to treat HIV/AIDS and a vaccine to curb its spread (1-5). HIV/AIDS has grown to be one of the major causes of death in the United States. Approximately one million individuals in the United States are infected $(6,7)$, almost one quarter million have been diagnosed with AIDS, and approximately $65 \%$ of those individuals diagnosed with AIDS have died (8). The impact of HIV/AIDS on other parts of the world, particularly parts of Africa and Asia, will likely be more devastating than the impact on the United States if current trends continue (9). Since behavioural intervention approaches have not proven entirely successful and access to antiretroviral therapies is generally limited to developed countries, the major hope for curbing the HIV/AIDS epidemic worldwide is the development of an efficacious, inexpensive, easy to administer vaccine.

The combination of scientific challenges in HIV vaccine development is unparalleled in the field of vaccine development. First, the great degree of genetic diversity of HIV suggests that broadly cross-reactive immune responses will be needed to protect an individual from all subtypes of virus to which the individual might be exposed. Five major clades or subtypes of HIV-1 have been identified (10-12). The virus in each clade differs from virus in other clades by 30 to $35 \%$ in the genetic sequence of env and gag genes. Antigenic variation, which has hindered the development of the influenza vaccine, may prove to be an even more significant obstacle in the case of HIV-1. Second, the virus exists in both free virion and cell-associated forms. Vaccines that induce both neutralizing antibodies, which block infection by free virions, and cytotoxic T lymphocytes (CTL), which may eliminate infected cells, may be required. However, the nature and amount of HIV antigen expression on the surface of cells that are not actively producing virus remains unknown; latently infected cells might not be vulnerable to attack by either antibody or CTLS. Third, the major mode of transmission of HIV-1 is through sexual contact; an efficacious vaccine may require induction of HIV-1-specific mucosal immune responses through novel antigen presentation methods. Fourth, there is no documentation that individuals can completely clear HIV-1 from the body once infection is established. Thus, the immune response(s) that correlates with protection from HIV-induced disease is not known. Fifth, although monkeys infected with the simian immunodeficiency virus (siv) have proven useful in evaluating vaccine concepts, there is as yet no animal model that can be employed to determine the effectiveness of an HIV-1 candidate vaccine in preventing HIV-1-induced disease (13). HIV-1 can establish a chronic infection in chimpanzees, but does not cause immunodeficiency or disease. Thus, this expen- sive model can be used to evaluate the ability of candidate HIV-1 vaccines to block primary infection, but it will not provide information on the impact of the vaccine on disease induction or progression. Recent results with Macaca nemestrina suggest that this species can be acutely infected with HIV-1 (14); data are being accumulated to document the degree and reproducibility of this infection. Infection of monkeys with an HIV-SIV chimera, known as SHIV, may also prove valuable in the evaluation of certain candidate HIV vaccines (15).

Most viral vaccines licensed in the United States are whole-killed (inactivated) or live-attenuated products (16). Because of safety concerns associated with administration of a live-attenuated retrovirus vaccine or killed HIV virions to noninfected, healthy individuals, most vaccine manufacturers have elected either not to pursue HIV vaccine development or to pursue alternative approaches to antigen delivery. These approaches have included: recombinant viral and bacterial vectors engineered to express one or more HIV antigens; purified recombinant HIV proteins; pseudovirions and other noninfectious particles that lack HIV genomic RNA; synthetic HIV peptides; and other approaches (Table 1). Many of these candidate HIV vaccines have entered early stages of clinical trial in noninfected and/or infected individuals.

The most studied antigen in candidate HIV vaccines is the HIV envelope protein (17). The majority of neutralizing antibodies in HIV-infected individuals are directed against the HIV envelope (18-23). HIV envelope, as well as gag, pol and nef gene-encoded proteins, possess determinants recognized by CTL from HIV-infected individuals (24-32).

The HIV gp120 envelope protein is an extracellular glycoprotein that mediates the binding of HIV to the CD4 receptor of susceptible cells. Gp160 is a precursor protein that is cleaved during HIV replication into the mature extracellular gp120 and the transmembrance gp41 proteins. Gp160 and gp120 have been prepared as recombinant proteins from one or more expression systems employing insect, yeast and/or mammalian cells (33-40). The HIV-1 env gene has also been engineered into recombinant vaccinia virus, either alone or along with gag and pol genes $(41,42)$. More recently, recombinant canarypox vectors, which express gp160, entered clinical trial, and two envelope peptide-based vaccines entered clinical trial in 1993 (43-45). Other candidates being evaluated in noninfected individuals are based on the HIV p17 (HGP-30) (46) and p24 (Ty-gag) core (47) proteins.

Phase 1 testing in noninfected volunteers conducted by the National Institute of Allergy and Infectious Diseases (NIAID) AIDS Vaccine Evalution Group (AVEG) has yielded valuable information concerning the safety and immunogenicity of many of these first generation candidate vaccines (48-56). All HIV-1 vaccine candidates evaluated by the NIAID AVEG in noninfected individuals 
TABLE 1

Types of candidate HIV vaccines

\begin{tabular}{|c|c|c|}
\hline Candidate vaccine & Expression system/production methods & Developer \\
\hline \multicolumn{3}{|l|}{ Recombinant proteins } \\
\hline rgp $160^{* \dagger}$ & Baculovirus/insect & MicroGeneSys \\
\hline rgp 160* & Mammalian/vaccinia & Pasteur/Merieux Serums et Vaccins \\
\hline $\operatorname{rgp} 120(\text { env } 2-3)^{* \dagger}$ & Yeast & Biocine \\
\hline $\operatorname{rgp} 120^{*}+$ & Mammalian & Biocine \\
\hline \multicolumn{3}{|l|}{ Peptides } \\
\hline HGP-30* ${ }^{\dagger}$ & Synthetic p17 gag peptide & Viral Technologies, Inc \\
\hline $\mathrm{p} 24^{\dagger}$ & Baculovirus/insect & MicroGeneSys \\
\hline Ty.p24.VLP* & Yeast transposon product & British Bio-tech, Ltd \\
\hline V3-MAPS* & Synthetic & United Biomedical, Inc \\
\hline CP-gp 160* & Recombinant canarypox & Pasteur/Merieux Serums et Vaccins \\
\hline \multicolumn{3}{|l|}{ Other } \\
\hline Whole-inactivated $\mathrm{HIV}^{\dagger}$ & $\beta$-propiolactone and gamma irradiation & Immune Response Corp \\
\hline $\mathrm{rCD}^{\dagger}$ & Mammalian & Biogen \\
\hline anti-gp $120 \mathrm{lg}^{\dagger}$ & Monoclonal antibody & IDEC \\
\hline
\end{tabular}

have been safe and well tolerated. Observed side effects such as local pain and tenderness, low grade fever and minor systemic symptoms, some of which also occur in placebo recipients, are typical of those observed with other vaccines. (When the immune modulator muramyl tripeptide-phosphatidyl ethanolamene is added, fever and malaise have been more prominent.) No major side effects such as renal, hepatic or neurological toxicity have been reported.

With respect to immunogenicity, almost all products evaluated induce binding antibody lasting from weeks to months $(48,49,51,55,56)$. Almost all induce some level of functional antibody, usually against the strain of virus on which the vaccine is based. Functional antibody is defined here as antibody that can neutralize virus in an in vitro acute HIV infection assay and/or inhibit fusion (syncytia formation) between noninfected and infected cells in culture. Recent preliminary results suggest that gp120 may induce more functional antibody than gp 160 .

Recombinant (r) gp160 has also been evaluated in combination with recombinant live vaccinia virus genetically engineered to express the gp160 envelope protein (vac-env) $(54,56)$. After two priming doses of vac-env, little antibody was produced. Following subsequent immunization with gp 160, binding and functional antibody was elicited. Indeed, a higher percentage of individuals produced functional antibody to the vac-env plus gp 160 combination than to gp 160 alone in comparable immunization protocols (56).
Memory $\mathrm{T}$ cells may be essential to induction of a rapid protective immune response upon subsequent exposure to virus. HIV-specific lymphoproliferative responses to HIV antigen, indicative of HIV-specific $\mathrm{T}$ cell memory, have been induced by the candidate vaccines in every trial from which data are available (52-55). CTLs may be needed to clear virus-infected host cells and produce a 'sterilizing immunity'. Thus far, CD8+ major histocompatibility complex (MHC) class 1-restricted cytotoxic T lymphocytes (CD8+ CTL) have been observed only in volunteers immunized with vac-env followed by boosts with rgp160 (57,58; personal communication). CTLs cloned from selected volunteers demonstrated cytolytic activity specific for HIV-infected cells in vitro (57). The vac-env and gp160 combination also elicited CD4+ MHC class 2-restricted CTLS (CD4+ CTL). In one study, CD8+ CTL clones from these volunteers were more potent than CD4+ CTL in lysing Epstein-Barr virus-transformed autologous B cells transfected with a eukaryotic expression vector carrying the HIV envelope gene (57). One CD8+ clone lysed target cells at effector:target ratios as low as 0.03:1 (57). Furthermore, CD4+ CTL clones, but not CD8+ CTL clones, lysed gp120-pulsed noninfected cells, suggesting that CD4+ CTL might have a detrimental effect in the presence of significant levels of gp120, although the physiological significance of this observation remains unknown (57).

Peripheral blood lymphocytes isolated from selected volunteers primed with vac-env and then boosted with rgp 160 were able to protect severe combined immuno- 
deficiency mice from HIV infection (59). Protection correlated more closely with $\mathrm{T}$ cell proliferation responses than with the level of antibody in the donor. However, $100 \%$ protection was not achieved, and the number of protective cells waned with time after the gp 160 boost.

A number of novel adjuvants are being developed for use in human vaccine formulations $(60,61)$. Recent meeting reports of animal studies (62-64) suggest that, in addition to increasing the breadth, magnitude and duration of the antibody response, some of these novel adjuvants show promise in stimulating CD8+ CTL. Several of these adjuvants are expected to be employed in prototype HIV vaccine formulations in clinical trials in the near future, in hopes that both humoral and cellular HIV-specific immune responses can be elicited or augmented.

All products evaluated to date are based on HIV-1 LAI, HIV-1 MN or HIV-1 SF2, which are all laboratory strains of the virus that belong to the same clade or subtype of HIV-1. A high research priority is to determine the degree to which antibodies induced by these candidate vaccines recognize HIV isolated from infected individuals in the United States and other countries. Multiple products or cocktails of products may be required to achieve sufficiently broad immune responses.

\section{THERAPEUTIC VACCINES}

Approximately 11 products have entered phase 1 testing in HIV-infected volunteers. These include wholekilled HIV depleted of gp120, rgp160, rgp120 and other CD4 or antibody-based approaches $(17,48-56)$. Five phase 2 trials are in progress or soon to begin.

Most available information is from trials of a candidate HIV vaccine, rgp160, which include the only completed, double-blind, placebo controlled trials of rgp 160 in infected individuals (65). Candidates for which safety information has been made available have not elicited any significant toxicities $(65,66)$. Furthermore, rgp 120 and rgp160 have been shown to elicit both new humoral and new cellular immune responses in HIV-1infected individuals. Specifically, rgp160 has elicted new antibody responses directed against the $\mathrm{C} 1, \mathrm{C} 2, \mathrm{c} 3$ and v3 regions of the HIV envelope, augmented levels of HIV-specific CTLs, induced delayed-type hypersensitivity responses to HIV envelope and increased gp 160-specific lymphocyte proliferative responses.

Ongoing and planned placebo controlled phase 2 and 3 trials will help determine if any of these immune responses lead to changes in viral load and/or stabilization of CD4 cell counts. However, it is uncertain whether these virological markers prognosticate clinical outcome. Furthermore, clinical end-points in HIVinfected individuals with more than $500 \mathrm{CD} 4$ cells $/ \mathrm{mm}^{3}$ would take an inordinate time to reach. These considerations have led to a proposal that larger trials should begin in the absence of phase 2 data demonstrating that immunization leads to positive changes in progres- sion of infection (eg, CD4 stablization and viral load reduction) (67).

\section{SUMMARY}

Candidate HIV vaccines are being developed in hopes that one or more will protect noninfected individuals from infection upon subsequent exposure to virus, and/or will elicit new responses of therapeutic benefit in individuals in whom infection is already established. Safety concerns associated with the more traditional approaches of vaccine design, combined with the opportunities provided by advances in biotechnology, have resulted in the pursuit of numerous HIV-1 vaccine designs. The techniques of molecular biology are being applied to an unprecedented extent in the design and delivery of candidate HIV-1 vaccines. Most prototype vaccines are purified recombinant HIV envelope proteins. Results with these products have been encouraging. All products for which information is available have proven safe and immunogenic in noninfected and/or infected individuals. Additional information on the duration, breadth and functionality of the immune responses will be needed before efficacy trials in noninfected individuals are likely to begin. Important information on the benefit of HIV vaccines in infected individuals will likely emerge in the next few years.

Additional novel candidate vaccines are in earlier stages of development, entering human trials in 1993 and beyond. These include viral and bacterial vectors that express one or more HIV proteins, peptide-based approaches, new particle designs and others. In addition, the success of live-attenuated sIV in protecting monkeys from infection by SIV has resulted in renewed interest in live-attenuated designs as prophylactic vaccines $(68,69)$. Should problems or disappointing results with current prophylactic candidates arise, the risks and benefits of live-attenuated products will have to be reconsidered. In the interim, additional preclinical and safety and efficacy studies of live-attenuated and other novel designs is of high priority.

\section{REFERENCES}

1. Gottlieb MS, Schroff R, Schanker HM, et al. Pneumocystis carinii pneumonia and mucosal candidiasis in previously healthy homosexual men: Evidence of a new acquired cellular immunodeficiency. N Engl J Med 1981;305: 1425.

2. Masur H, Michelis MA, Greene JB, et al. An outbreak of community-acquired Pneumocystis carinii pneumonia: Initial manifestations of cellular immune dysfuction. N Engl J Med 1981;305:1431.

3. Seigal FP, Lopez C, Hammer GS, et al. Severe acquired immunodeficiency in male homosexuals, manifested by chronic perianal ulcerative herpes simplex lesions. N Engl J Med 1981;305:1439.

4. Gallo RC, Sarin PS, Gelmann EP, et al. Isolation of human T-cell leukemia virus in acquired immune deficiency syndrome (AIDS). Science 1983;220:865-7.

5. Barre-Sinoussi F, Chermann J-C, Rey F, et al. Isolation of T-lymphotropic retrovirus from a patient at risk for acquired immune deficiency syndrome (AIDS). Science 
1983:220:868

6. Brookmeyer R. Reconstruction and future trends of the AIDS epidemic in the United States. Science $1991 ; 253: 37-42$.

7. Vermund SH. Changing estimates of HIV-1 seroprevalence in the United States. J NIH Res 1991:3:77-81.

8. Centers for Disease Control and Prevention. HIV/AIDS Surveillance Report, February 1993. 1993:1-23.

9. Heymann D. HIV/AIDS: The global epidemic. AIDS Res Hum Retroviruses 1993;9:s13-5.

10. Myers G, Korber B, Berzofsky J, Smith R, Pavlakis GN, eds. Human Retroviruses and AIDS, a Compilation and Analysis of Nucleic Acid and Amino Acid Sequences 1992 Los Alamos: Los Alamos National Laboratory, T-10, 1992.

11. Korber B, Gifford A, Myers G. Patterns of variation among international isolates in the highly immunogenic V3 region of the HIV-1 envelope protein. AIDS Res Hum Retroviruses 1993;9:S98.

12. Myers G, Korber B. The future of HIV in evolutionary biology of viruses. Morse SS, ed. New York: Raven Press, 1993.

13. Schultz AM, Hu S-L. Primate models for HIV vaccines. AIDS 1993:7:S161-70.

14. Agy MB, Frumkin LR, Corey L, et al. Infection of Macaca nemestrina by human immunodeficiency virus type- 1 . Science 1992;257:103-6.

15. Li J, Lord CI, Haseltine W, Letvin NL, Sodroski J. Infection of cynomolgus monkeys with a chimeric HIV-1/SIVmac virus that expresses the HIV-1 envelope glycoproteins. J Acquir Immune Defic Syndr 1992;5:639-46.

16. Ada GL. Vaccines. In: Paul WE, ed. Fundamental Immunology. New York: Raven Press, 1989:985-1032.

17. Fast P. Walker MC. Human trials of experimental AIDS vaccines. AIDS 1993;7:S147-59.

18. Ho DD, Sarngaharan MG, Hirsch MS, et al. Human immunodeficiency virus neutralizing antibodies recognize several conserved domains on the envelope glycoproteins. J Virol 1987:61:2024-8.

19. Rusche JR, Javaherian J, McDanal C, et al. Antibodies that inhibit fusion of human immunodeficiency virus-infected cells bind a 24-amino acid sequence of the viral envelope, gp 120. Proc Natl Acad Sci USA 1988;85:3198-202.

20. Putney SD, Matthew TJ, Robey WG, et al. HTLV-III/LAV neutralizing antibodies to an E. coli-produced fragment of the virus envelope. Science 1986;234:1392-5.

21. Palker TJ, Clark ME, Langlois AJ, et al. Type specific neutralization of the human immunodeficiency virus with antibodies to env-encoded synthetic peptides. Proc Natl Acad Sci USA 1988;85:1932-6.

22. Javaherian K, Langlois AJ, McDanal C, et al. Principal neutralizing domain of the human immunodeficiency virus type 1 envelope protein. Proc Natl Acad Sci USA 1989:86:6768-72.

23. LaRosa GJ, Davide JP, Weinhold K, et al. Conserved sequence and structural elements in the HIV-1 principal neutralizing domain. Science 1990;249:932-5.

24. Berzofsky JA, Bensussan A, Cease KB, et al. Antigenic peptide recognized by $\mathrm{T}$ lymphocytes from AIDS viral envelope-immune humans. Nature 1988;334:706-8.

25. Takahashi H, Cohen J, Hosmalin A, et al. An immunodominant epitope of the human immunodeficiency virus envelope glycoprotein gp160 recognized by class I major histocompatibility complex molecule-restricted murine cytotoxic T lympocytes. Proc Natl Acad Sci USA 1988;85:3105-9.
26. Wahren B, Rosen J, Sandstrom E, Mathieson T, Modrow $\mathrm{S}$, Wigzell H. HIV-1 peptides induce a proliferative response in lymphocytes from infected persons. J AIDS 1989;2:448-56.

27. Walker BD, Chakrabarti S, Moss B, et al. HIV-specific cytotoxic T lymphocytes in seropositive individuals. Nature 1987;328:345-8.

28. Plata F, Autran B, Pedroza-Martins LP, et al. AIDS virus-specific cytotoxic T lymphocytes in lung disorders. Nature 1987;328:348-51.

29. Koenig S, Earl P, Powell D, et al. Group-specific, major histocompatibility complex class I-restricted cytotoxic responses to human immunodeficiency virus 1 (HIV-1) envelope proteins by cloned peripheral blood T cells from an HIV-1 infected individual. Proc Natl Acad Sci USA $1988 ; 85: 8638-42$.

30. Riviere Y, Tanneau-Salvadori F, Regnault A, et al. Human immunodeficiency virus-specific cytotoxic responses of sero-positive individuals: Distinct types of effector cells mediate killing of targets expressing gag and env proteins. J Virol 1989;63:2270-7.

31. Walker BD, Flexner C, Paradis TJ, et al. HIV-1 reverse transcriptase is a target for cytotoxic T lymphocytes in infected individuals. Science 1988;240:64-6.

32. Koup RA, Sullivan JL, Levine PH, et al. Detection of major histocompatibility complex class-I restricted, HIV-specific cytotoxic T lymphocytes in the blood of infected hemophiliacs. Blood 1989;73:1909-14.

33. Dolin R, Graham BS, Greenberg SB, et al. Safety and immunogenicity of a human immunodeficiency virus type 1 (HIV-1) recombinant gp 160 candidate vaccine in humans. Ann Intern Med 1991;114:119-27.

34. Fuerst TR, Earl PL, Moss B. Use of a hybrid vaccinia virus-T7 RNA polymerase system for expression of target genes. Mol Cell Biol 1987;7:2538-44.

35. Barrett N, Mitterer A, Mundt W, et al. Large scale production and purification of a vaccinia-derived HIV-1 gp 160 and analysis of its immunogenicity. AIDS Res Hum Retroviruses 1989;5:159-71.

36. Steimer KS, Van Nest G, Dina D, Barr PJ, Luciw PA, Miller ET. Genetically engineered human immunodeficiency virus envelope glycoprotein gp120 produced in yeast is the target of neutralizing antibodies. In: Ginsberg H, Brown F, Lerner RA, Chanock RM, eds. Vaccines 87. Cold Spring Harbor: Cold Spring Harbor Press, 1987:236-41.

37. Haigwood NL, Nara PL, Brooks E, et al. Native but not denatured recombinant human immunodeficiency virus type 1 gp120 generates broad-spectrum neutralizing antibodies in baboons. J Virol 1992;66:172-82.

38. Berman PW, Gregory TJ, Riddle L, et al. Protection of chimpanzees from infection by HIV-1 after vaccination with recombinant glycoprotein gp 120 but not gp 160 . Nature 1990;345:622-5.

39. Lasky LA, Groopman JE, Fennie CW, et al. Neutralization of the AIDS retrovirus by antibodies to a recombinant envelope glycoprotein. Science 1986;233:209-12.

40. Berman PW, Riddle L, Nakamura G, et al. Expression and immunogenicity of the extracellular domain of the human immunodeficiency virus type 1 envelope glycoprotein, gp160. J Virol 1989;63:3489-98.

41. Hu SL, Kosowski SG, Dalrymple JM. Expression of AIDS virus envelope in recombinant vaccinia viruses. Nature 1986;320:537-9.

42. Tartaglia J, Cox WI, Taylor J, et al. Highly attenuated poxvirus vectors. AIDS Res Hum Retroviruses 1992;8:1445-7.

43. Palker TJ, Matthews TJ, Langlois A, et al. Polyvalent 
human immunodeficiency virus synthetic immunogen comprised of [sic] envelope gp120 T helper cell sites and B cell neutralization epitopes. J Immunol 1989; 142:3612-9.

44. Hart MK, Palker TJ, Matthews TJ, et al. Synthetic peptides containing $\mathrm{T}$ and $\mathrm{B}$ cell epitopes from human immunodeficiency virus envelope gp 120 induce anti-HIV proliferative responses and high titers of neutralizing antibodies in rhesus monkeys. J Immunol 1990; 145:2677-85.

45. Wang CY, Looney DJ, Li ML, et al. Long-term high-titer neutralizing activity induced by octameric synthetic HIV-1 antigen. Science 1991;254:285-8.

46. Goldstein AL, Naylor PH, Sarin PS, et al. Progress in the development of a p17 based HIV vaccine: Immunogenicity of HGP-30 in humans. VII International Conference on AIDS. Florence, June 1991. (Abst MA1342)

47. Adams SE, Dawson KM, Gull K, Kingsman SM, Kingsman AJ. The expression of hybrid HIV:Ty virus-like particles in yeast. Nature 1987;329:68-70.

48. Dolin R, Graham BS, Greenberg SB, et al. Safety and immunogenicity of a human immunodeficiency virus type 1 (HIV-1) recombinant gp 160 candidate vaccine in humans. Ann Intern Med 1991;114:119-27.

49. Viscidi R, Ellerbeck E, Garrison L, et al. Characterization of serum antibody responses to recombinant HIV-1 gp 160 vaccine by enzyme immunoassay. AIDS Res Hum Retroviruses 1990;6:1251-6.

50. Graham BS, Belshe RB, Clements ML, et al. Vaccination of vaccinia-naive adults with HIV-1 gp160 recombinant vaccinia (HIVAC-1e) in a blinded, controlled, randomized clinical trial. J Infect Dis 1992;166:244-52.

51. Cooney EL, Collier AC, Greenberg PD, et al. Safety of and immunological response to a recombinant vaccinia virus vaccine expressing HIV envelope glycoprotein. Lancet 1991;337:567-72.

52. Keefer MC, Bonnez W, Roberts NJ Jr, Dolin R, Reichman RC. Human immunodeficiency virus (HIV-1) gp160-specific lymphocyte proliferative responses of mononuclear leukocytes from HIV-1 recombinant gp 160 vaccine recipients. J Infect Dis 1991;163:448-53.

53. Gorse GJ, Belshe RB, Newman FK, Frey SE, NIAID AIDS Vaccine Clinical Trials Network. Lymphocyte proliferative responses following immunization with human immunodeficiency virus recombinant gp 160. Vaccine 1992;10:383-8.

54. Cooney E, McElrath MJ, Corey L, et al. Enhanced immunity to HIV envelope elicited by a combined vaccine regimen consisting of priming with a vaccinia recombinant expressing HIV envelope and boosting with gp160 protein. Proc Natl Acad Sci USA 1993;90:1882-6.

55. Graham BS, Belshe RB, Clements ML, et al. Vaccination of vaccinia-naive adults with HIV-1 gp 160 recombinant vaccinia in a blinded, controlled, randomized clinical trial. J Infect Dis 1992;166:244-52.

56. Graham BS, Matthews TJ, Belshe RB, et al.
Augmentation of HIV-1 neutralizing antibody by priming with gp 160 recombinant vaccinia and boosting with rgp 160. J Infect Dis 1993; 167:533-7.

57. Hammond SA, Bollinger RC, Stanhope PE, Quinn TC, Clements ML, Siliciano RF. Immunization with HIV-1 env-recombinant vaccinia and purified HIV-1 gp 160 induces HIV-1 specific CD8+ human cytolytic T cells. J Exp Med 1993;176:1531-42.

58. El-Daher N, Keefer MC, Reichman RC, Dolin R, Roberts NJ Jr. Persisting HIV-1 gp 160-specific human T lymphocyte responses after receipt of vaccinia recombinant and purified subunit HIV-derived envelope vaccines. AIDS Res Hum Retroviruses 1993:9:S79.

59. Mosier DE, Gulizia RJ, MacIssac PD, Corey L, Greenberg PD. Resistance to HIV-1 infection of SCID mice reconstituted with peripheral blood leukocytes from donors vaccinated with vaccinia-gp 160 and recombinant gp 160. Proc Natl Acad Sci USA 1993;90:2443-7.

60. Edelman R. An update on vaccine adjuvants in clinical trial. AIDS Res Hum Retroviruses 1992;8:1409-11.

61. Alving CR, Glass M, Detrick B. Summary; Adjuvants/clinical trials working group. AIDS Res Hum Retroviruses 1992;8:1427-30.

62. Newman MN, Wu J-Y, Gardner BH, Munroe KJ, Kensil CR, Wyand MS. Saponin (QS-21) adjuvant activity in nonhuman primates. AIDS Res Hum Retroviruses 1993;9:S94.

63. Murphey-Corb M, Ohkawa S, Wilson L, Bohm R, Detrick B. Comparative immune responses in macaques immunized with inactivated SIV in combination with 9 different adjuvants. AIDS Res Hum Retroviruses 1993:9:S92.

64. Letvin NL, Miller MD, Gould-Fogerite S, et al. Vaccination of rhesus monkeys with synthetic peptide in a fusogenic proteoliposome elicits simian immunodeficiency virus-specific CD8+ cytotoxic T lymphocytes. AIDS Res Hum Retroviruses 1993;9:S93.

65. Kundu SK, Katzenstein DK, Moses LE, Merigan TC. Enhancement of human immunodeficiency virus (HIV)-specific CD4+ and CD8+ cytotoxic T-lymphocytes activities in HIV-infected asymptomatic patients given recombinant gp 160 vaccine. Proc Natl Acad Sci USA 1993:89:11204-8.

66. Redfield RR, Birx DL, Ketter N, et al. A phase I evaluation of the safety and immunogenicity of vaccination with recombinant gp 160 in patients with early human immunodeficiency virus infection. N Engl J Med 1991;324:1677-84.

67. Cohen J. MicroGeneSys vaccine trial gets a public peer review. Science 1992;258:1079-80.

68. Daniel MD, Kirchoff F, Czajak SC, Sehgal PK, Derosier RC. Protective effects of a live attenuated SIV vaccine with a deletion in the nef gene. Science 1992;258:1938-41.

69. Marthas ML, Miller CJ. Systemic and mucosal immune responses to live-attenuated and whole-inactivated SIV vaccines. Vaccine 1992;1:303-10. 


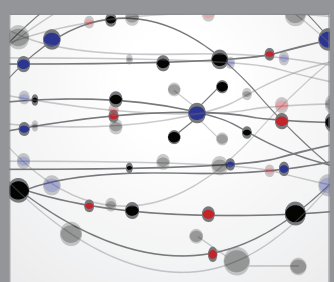

The Scientific World Journal
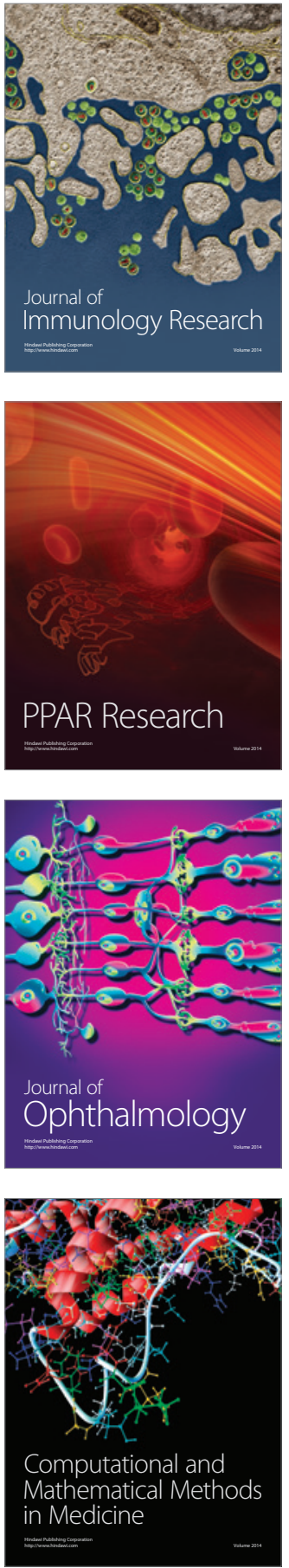

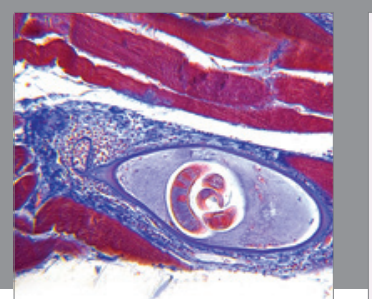

Gastroenterology Research and Practice

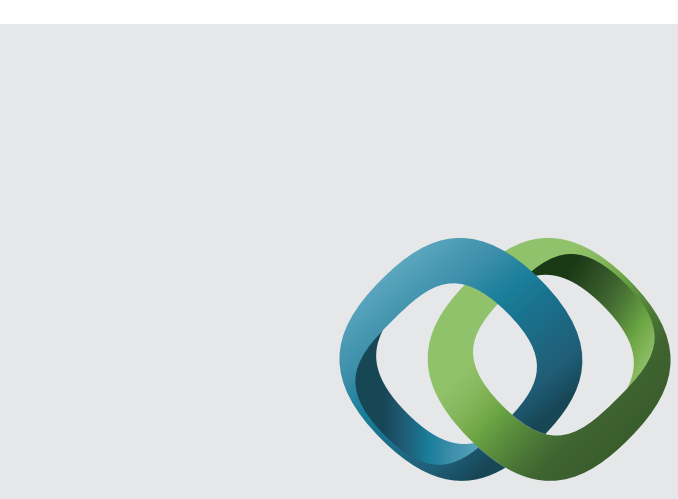

\section{Hindawi}

Submit your manuscripts at

http://www.hindawi.com
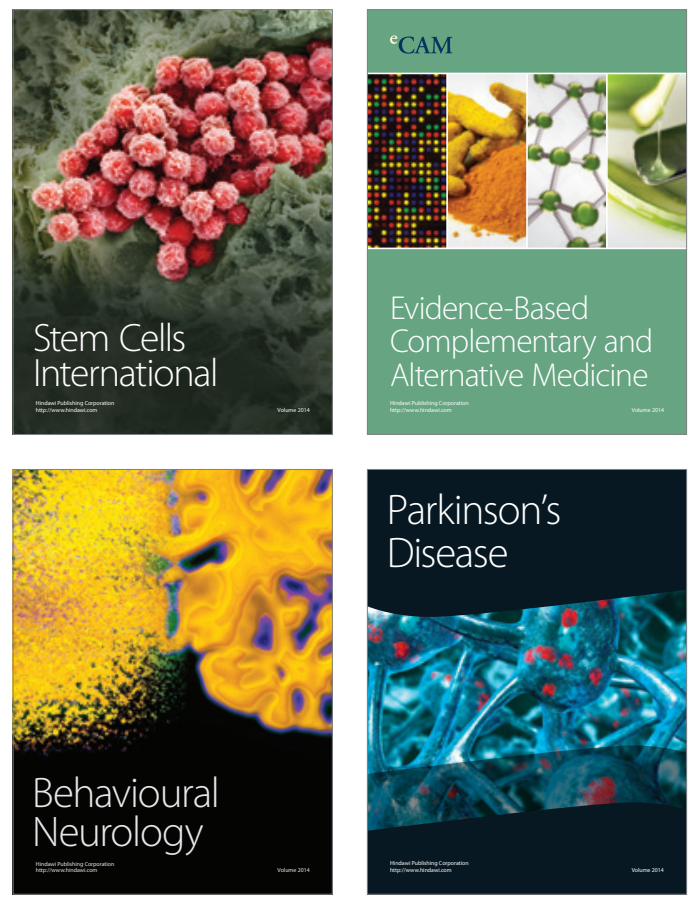
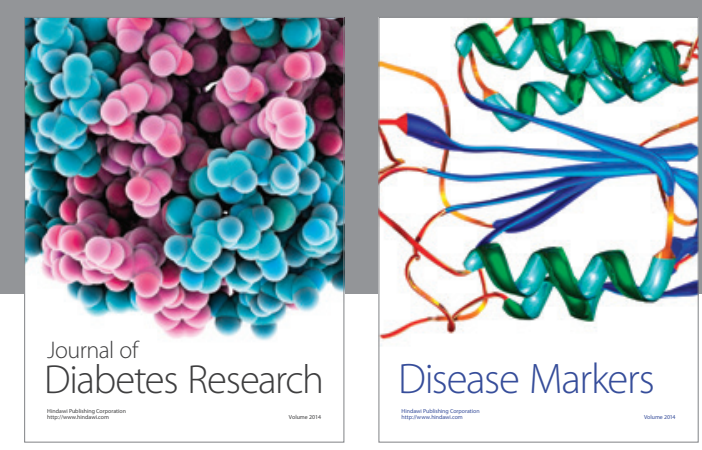

Disease Markers
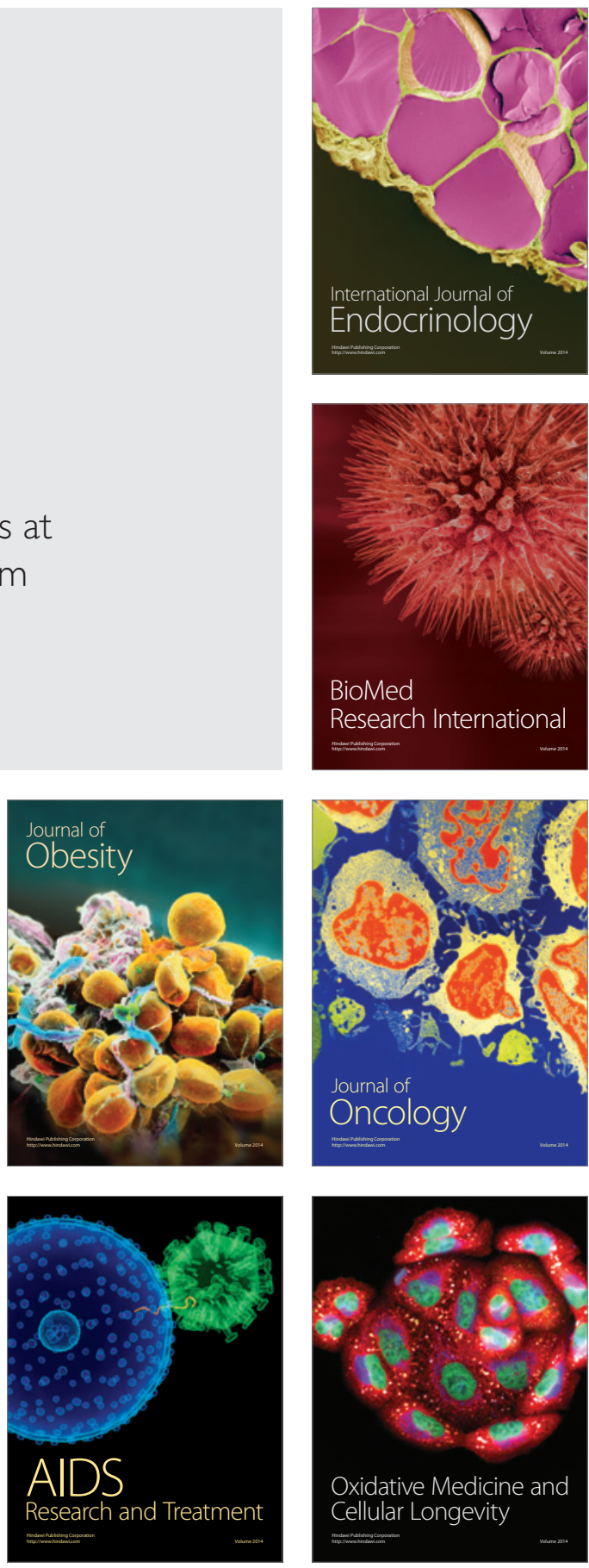